\title{
Morphological and Morphometric Insights of Gonocerca phycidis from the Brushtooth Lizardfish Saurida undosquamis
}

\author{
Sherein Maher ${ }^{1}$, Rania Abdel-Gaber ${ }^{2}$, Rewaida Abdel-Gaber ${ }^{2,3 *}$ \\ ${ }^{1}$ Zoology Department, Faculty of Women for Arts, Science and Education, Ain Shams University, Heliopolis, Egypt \\ ${ }^{2}$ Zoology Department, Faculty of Science, Cairo University, Cairo, Egypt \\ ${ }^{3}$ Zoology Department, College of Science, King Saud University, Riyadh, Saudi Arabia
}

*Corresponding Author: Rewaida Abdel-Gaber, Zoology Department, College of Science, King Saud University, Riyadh, Saudi Arabia.

\begin{abstract}
This parasitological study was conducted between January to December 2019 to investigate the helminth parasites infecting the Brushtooth lizardfish Saurida undosquamis in Hurghada city at the Gulf of Suez, Red Sea, Egypt. The prevalence of Gonocerca phycidis was $9.09 \%$ in the fish studied. The extent of G. phycidis infection is determined by the seasonal prevalence. It is shown that the incidence of infection was only $18.18 \%$ in the winter season. Morphological characteristics for the present parasite species revealed that it possesses a pre-testicular ovary, a vitellarium consisting of two lateral masses at the same level as the ovary, eggs without filaments, a terminal part of the male duct consisting of a seminal vesicle, a tubular pars prostatica surrounded by a subglobular field of prostatic cells, and a short ejaculatory duct opening into the genital atrium. Moreover, morphometric analysis revealed little differences in measurements with other species of Gonocerca.
\end{abstract}

Keywords: Saurida undosquamis; Derogenidae; Gonocerca spp.; Morphological description

\section{INTRODUCTION}

The genus Gonocerca Manter [1] is known to be a member of the subfamily Gonocercinae Skrjabin and Guschanskaja [2], within the family Derogenidae Nicoll [3]. The taxonomic status of this genus is controversial, as there are plenty of nominal species [4-7], many of which may be synonymous with G. phycidis Manter [1]. G. phycidis is a bipolar species found in archybenthal waters in a wide range of hosts. The recorded species are found in Canadian water are G. phycidis, G. crassa Manter [8], G. macroformis Wolfgang and Myers [9], and G. macrouri Gaevskaya [10]. Subsequently, the reports of G. crassa by Ronald [11] from Pleuronectes ferrugineus, by Szuks [12] from Coryphaenoides rupestris, and by Zubchenko [13] from Macrourus berglax can probably be attributed to G. phycidis, as material in the BM (NH) from these or related hosts from both sides of the Atlantic belong to this species. In addition, the distinctive characteristics of G. crassa mentioned by Brinkmann [14] require confirmation, since the position of the genital pore relative to the oral sucker appears to be a function of contraction. In addition, G. macrouri originally described from Coryphaenoides rupestris from the North-East Atlantic, appears to be a synonym for G. phycidis, commonly found in this host on both sides of the Atlantic. Zubchenko [13] reported G. macrouri in Canadian waters. There is only the original record of G. macroformis from the ovary of Gadus morhua, Glyptocephalus cynoglossus, Hippoglossoides platessoides in Newfoundland waters, except for a single specimen that Zubchenko [13] claimed to have found in Coryphaenoides rupestris off Labrador. It should also be noted that in the Hudson Canyon off northeast United States, Campbell and Munroe [15] identified three species of Gonocerca from macrourids. These were G. phycidis from Coryphaenoides armatus and two other species, G. minuta from Nezumia bairdii and G. haedrichi from C. armatus.

The purpose of this study is to provide a comprehensive data on G. phycidis infecting the Brushtooth lizardfish Saurida undosquamis from the Gulf of Suez in the Red Sea, as well as to observe how much host- and site-induced variation in size and morphology occurs in this derogenid species. 


\section{Materials AND Methods}

Forty-four specimens of the Brushtooth lizardfish Saurida undosquamis (Family: Synodontidae) were collected between January - December 2019 from the coastal region of the Hurghada city in the Gulf of Suez, Red Sea, Egypt. The collected fish specimens were dissected and internal organs were examined for parasite detection. According to Bush et al. [16], prevalence of the recovered parasites was estimated. Trematode parasites were isolated, fixed in buffered formalin solution (10\%), stained with Semichon's aceto-carmine for $3 \mathrm{~h}$, ascending series of alcohol used for dehydration, then cleared in xylene and mounted on Canada balsam. Leica DM 2500 microscopy (NIS ELEMENTS software, ver. 3.8) was used to photograph the recovered parasites. Measurements were represented in millimeters for different body parts as mean \pm SD followed by range in parentheses.

\section{ReSUlts}

Of the Forty-four specimens of the Brushtooth lizardfish Saurida undosquamis, four (9.09\%) were found to be infected with Gonocerca phycidis. The infestation was recorded in the stomach. Seasonally, only $18.18 \%$ (4 out of 22) of the infestation was recorded in the winter season.

Description (Fig. 1a-e; Table 1)

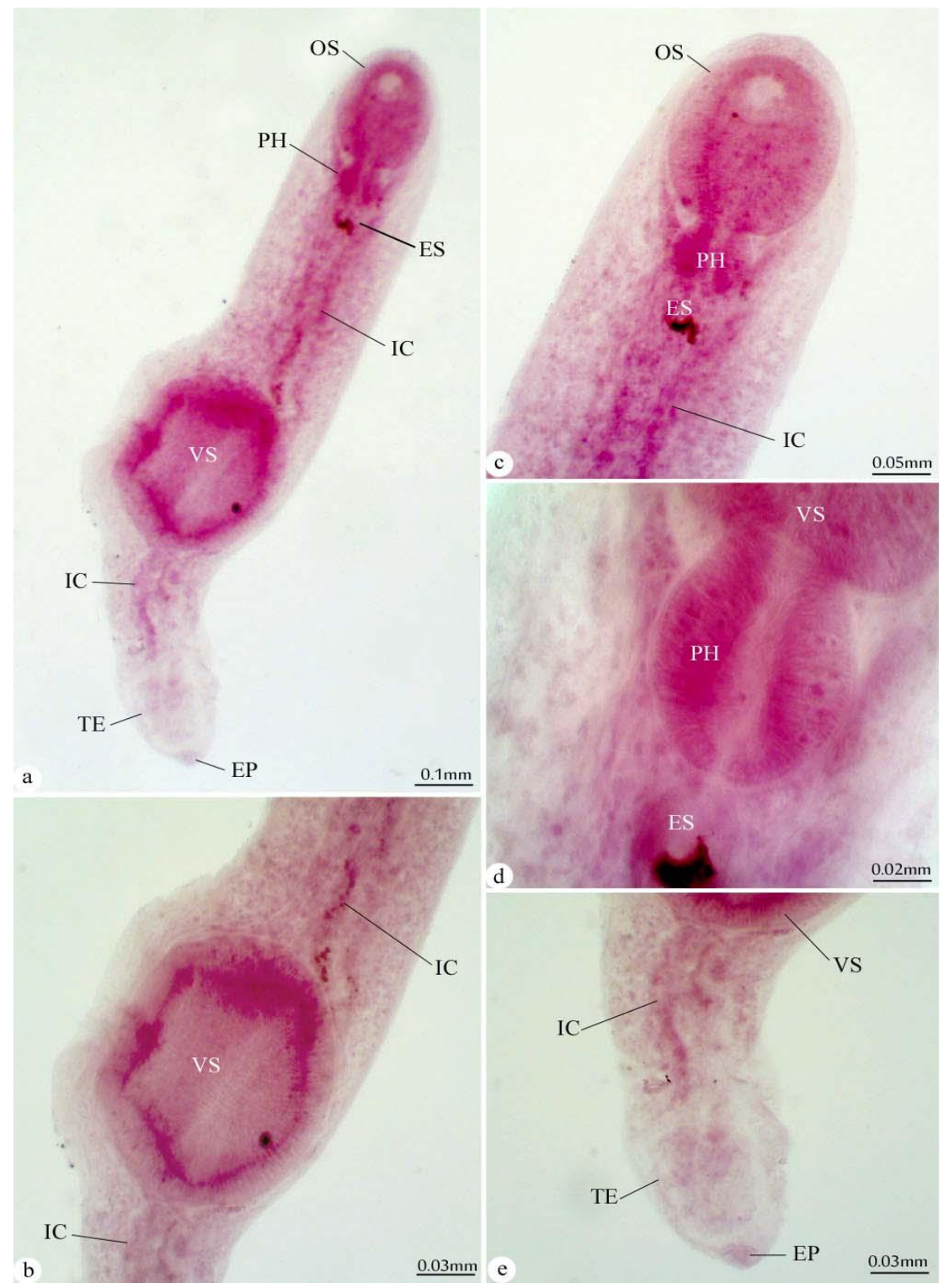

Fig 1. a-e Photomicrographs of the adult digenea G. phycidis infecting S. undosquamis. a. The adult worm with oral sucker $(O S)$, pharynx (PH), esophagus (ES), ventral sucker (VS), intestinal caeca (IC), testes (TE), and terminal excretory pore (EP). b-e. High magnifications of: b,c. The anterior part of the body showing oral sucker (OS), pharynx (PH), and esophagus (ES). d,e. Ventral sucker (VS), testes (TE), and excretory pore (EP). 
Morphological and Morphometric Insights of Gonocerca phycidis from the Brushtooth Lizardfish Saurida undosquamis

Table 1. Comparative measurements (in millimeters) of the present Gonocerca phycidis and those described previously

\begin{tabular}{|c|c|c|c|c|c|c|}
\hline \multicolumn{2}{|c|}{$\begin{array}{c}\text { Species } \\
\text { Parameters }\end{array}$} & Gonocerca phycidis & G. phycidis & G. phycidis & G. phycidis & G. phycidis \\
\hline \multicolumn{2}{|l|}{ Host } & $\begin{array}{c}\text { Pseudochaenichthys } \\
\text { georgianus }\end{array}$ & $\begin{array}{c}\text { Macroronusm } \\
\text { agellanicus }\end{array}$ & $\begin{array}{c}\text { Macrourus } \\
\text { berglax }\end{array}$ & $\begin{array}{l}\text { Seriolella } \\
\text { porosa }\end{array}$ & $\begin{array}{c}\text { Saurida } \\
\text { undosquamis }\end{array}$ \\
\hline \multicolumn{2}{|l|}{ Host locality } & South Georgia & $\begin{array}{c}\text { San Matías } \\
\text { Gulf, } \\
\text { Argentina }\end{array}$ & $\begin{array}{l}\text { Admiralty } \\
\text { Bay, Indian } \\
\text { Ocean }\end{array}$ & $\begin{array}{c}\text { San Matías } \\
\text { Gulf, } \\
\text { Argentina }\end{array}$ & $\begin{array}{l}\text { Red Sea, } \\
\text { Egypt }\end{array}$ \\
\hline \multicolumn{2}{|l|}{ Reference } & Zdzitowiecki [27] & $\begin{array}{l}\text { Suriano and } \\
\text { Sutton [28] }\end{array}$ & $\begin{array}{c}\text { Kellermanns } \\
\text { et al. [29] }\end{array}$ & $\begin{array}{c}\text { Guagliardo } \\
\text { et al. [21] }\end{array}$ & $\begin{array}{c}\text { (Present } \\
\text { study) }\end{array}$ \\
\hline \multirow{2}{*}{ Body } & $\mathbf{L}$ & $2.69-6.34$ & $2.600-4.000$ & $2.39-4.18$ & 1.850 & $\begin{array}{l}2.86-3.92 \\
(3.22 \pm 0.1)\end{array}$ \\
\hline & $\mathbf{W}$ & $0.56-1.10$ & $0.850-1.100$ & $0.78-2.36$ & 0.450 & $\begin{array}{c}0.58-1.32 \\
(1.10 \pm 0.1)\end{array}$ \\
\hline \multirow{2}{*}{$\begin{array}{l}\text { Oral } \\
\text { sucker }\end{array}$} & $\mathbf{L}$ & $0.320-0.600$ & $0.300-0.350$ & $0.27-0.42$ & 0.200 & $\begin{array}{c}0.29-0.48 \\
(0.35 \pm 0.01)\end{array}$ \\
\hline & $\mathbf{W}$ & $0.340-0.630$ & $0.550-0.600$ & $0.11-0.34$ & 0.232 & $\begin{array}{c}0.27-0.40 \\
(0.35 \pm 0.01)\end{array}$ \\
\hline \multirow[t]{2}{*}{$\begin{array}{l}\text { Ventral } \\
\text { sucker }\end{array}$} & $\mathbf{L}$ & $0.470-0.880$ & $0.700-0.750$ & $0.49-0.76$ & 0.310 & $\begin{array}{c}0.49-0.68 \\
(0.54 \pm 0.01)\end{array}$ \\
\hline & $\mathbf{W}$ & $0.490-0.900$ & $0.900-0.950$ & $0.49-0.87$ & 0.400 & $\begin{array}{c}0.50-0.95 \\
(0.83 \pm 0.01) \\
\end{array}$ \\
\hline \multicolumn{2}{|l|}{$\begin{array}{l}\text { Oral sucker/ } \\
\text { acetabulum } \\
\text { ratio }\end{array}$} & $\begin{array}{l}1: 0.27-1: 0.36 \\
\quad(1: 0.33)\end{array}$ & $1: 2-3$ & ---- & $1: 1.64$ & $\begin{array}{c}1: 0.41 \\
(0.24-0.46)\end{array}$ \\
\hline \multirow{2}{*}{ Pharynx } & $\mathbf{L}$ & $0.120-0.210$ & $0.090-0.095$ & $0.10-0.14$ & 0.090 & $\begin{array}{c}0.11-0.21 \\
(0.18 \pm 0.01)\end{array}$ \\
\hline & $\mathbf{W}$ & $0.120-0.220$ & $0.150-0.160$ & -- & 0.080 & $\begin{array}{c}0.07-0.12 \\
(0.09 \pm 0.001) \\
\end{array}$ \\
\hline \multirow{2}{*}{$\begin{array}{l}\text { Anterior } \\
\text { testis }\end{array}$} & $\mathbf{L}$ & $0.280-0.840$ & ---- & $0.23-0.40$ & 0.150 & $\begin{array}{c}0.19-0.34 \\
(0.23 \pm 0.01)\end{array}$ \\
\hline & $\mathbf{W}$ & $0.350-0.720$ & ---- & $0.19-0.31$ & 0.150 & $\begin{array}{c}0.23-0.43 \\
(0.39 \pm 0.01)\end{array}$ \\
\hline \multirow{2}{*}{$\begin{array}{l}\text { Posterior } \\
\text { testis }\end{array}$} & $\mathbf{L}$ & ---- & ---- & $0.12-0.66$ & ---- & $\begin{array}{c}0.15-0.23 \\
(0.20 \pm 0.01)\end{array}$ \\
\hline & $\mathbf{W}$ & ---- & ---- & $0.10-0.54$ & ---- & $\begin{array}{c}0.12-0.27 \\
(0.27 \pm 0.01)\end{array}$ \\
\hline \multirow{2}{*}{ Ovary } & $\mathbf{L}$ & $0.250-0.510$ & ---- & $0.04-0.06$ & 0.100 & $\begin{array}{c}0.13-0.37 \\
(0.25 \pm 0.01)\end{array}$ \\
\hline & $\mathbf{W}$ & $0.240-0.460$ & ---- & 0.02 & 0.095 & $\begin{array}{c}0.12-0.31 \\
(0.26 \pm 0.01)\end{array}$ \\
\hline \multicolumn{2}{|l|}{$\begin{array}{l}\text { Number of } \\
\text { vitellarian } \\
\text { lobes }\end{array}$} & 2 compacted lobes & $\begin{array}{l}2 \text { compacted } \\
\text { lobes }\end{array}$ & $\begin{array}{l}2 \text { compacted } \\
\text { lobes }\end{array}$ & $\begin{array}{c}2 \text { compacted } \\
\text { lobes }\end{array}$ & $\begin{array}{c}2 \text { compacted } \\
\text { lobes }\end{array}$ \\
\hline \multirow{2}{*}{ Egg } & $\mathbf{L}$ & ---- & 0.040 & ---- & 0.030 & $\begin{array}{c}0.039-0.057 \\
(0.040 \pm 0.01)\end{array}$ \\
\hline & $\mathbf{W}$ & ---- & 0.020 & --- & 0.016 & $\begin{array}{c}0.012-0.032 \\
(0.020 \pm 0.01)\end{array}$ \\
\hline
\end{tabular}

Body anterior sub-cylindrical, posterior body fusiform. Length: $3.22 \pm 0.1$ (2.86-3.92) mm; width $1.10 \pm 0.1 \quad(0.58-1.32) \mathrm{mm}$. Oral sucker sub-terminal; length $0.35 \pm 0.01 \quad(0.29-0.48) \mathrm{mm}$, width $0.35 \pm 0.01(0.27-0.40) \mathrm{mm}$. Pharynx rounded; length $0.18 \pm 0.01(0.11-0.21) \mathrm{mm}$, width $0.09 \pm 0.001$ (0.07-0.12) mm; pre-pharynx absent; esophagus short; ceca mildly inflated, extending to posterior 
extremity of body. Ventral sucker post-equatorial, sub-spherical; length $0.54 \pm 0.01(0.49-0.68) \mathrm{mm}$, width: $0.83 \pm 0.01(0.50-0.95) \mathrm{mm}$. Oral/ventral sucker ratio 1:0.41 (0.24-0.46). Testes diagonal at posterior extremity of body. Anterior testis length: $0.23 \pm 0.01(0.19-0.34) \mathrm{mm}$, width: $0.39 \pm 0.01$ (0.23-0.43) mm. Posterior testis length: $0.20 \pm 0.01(0.15-0.23) \mathrm{mm}$, width: $0.27 \pm 0.01(0.12-0.27) \mathrm{mm}$. Cirrus pouch elongated with slightly inflated posterior portion with tubular seminal vesicle. Pars prostatica short, surrounded by glandular prostatic cells, close to oral sucker. Genital atrium small with median genital pore, between two oral lobes at the posterior of ventral margin of oral sucker. Ovary between anterior testis and ventral sucker, overlapping former and almost closely to latter; subspherical; length: $0.25 \pm 0.01(0.13-0.37) \mathrm{mm}$, width: $0.26 \pm 0.01(0.12-0.31) \mathrm{mm}$. Vitellaria divided into two compact masses, bi-lobed, lying dorso-lateral to ovary. Seminal receptacle small, tubular, lying ventral to ovary and ventral sucker. Uterus without descending limb, winding forward between ovary and oral sucker, filling all available space, ending in a weakly developed metraterm entering genital atrium, filled with small numbers of eggs. Egg length: 0.040 $\pm 0.01 \quad(0.039-0.057) \mathrm{mm}$, width: $0.020 \pm 0.01(0.012-0.032) \mathrm{mm}$. Excretory pore terminal, with arms united dorsal of oral sucker.

\section{DISCUSSION}

Fishing is a very important part of the world's economic activities and it a crucial protein source for the local diet [17]. Fish generally have a wide range of ecto- and endo-parasites [18-20]. In the present study, the prevalence of infestation of the Brushtooth lizardfish S. undosquamis with G. phycidis was 9.09\%. These data agreed with that of Guagliardo et al. [21] who reported that Seriolella porosa was infested with G. phycidis (9.99\%). Gonocerca is a widespread genus erected by Manter [1] and characterized by an elongated body without spines, testes tandem to almost symmetrical at the posterior extremity of the body, median genital pore located in the posterior margin of the oral sucker, absent hermaphroditic duct and sinus-sac, small genital atrium, well-developed pars prostatica, small seminal vesicle located just posterior to the genital pore, medium-sized pre-testicular ovary and vitellaria in the form of more or less lobulated pre-testicular masses lateral to the ovary, and a slightly wider range of egg size variability. Based on the characteristics described above, the digenean species isolated in our study resembled the species of Gonocerca. There are several species described in the Gonocerca genus, namely G. phycidis Manter [1]; G. kobayashi Layman [22]; G. crassa Manter [8]; G. macroformis Wolfgang and Myers [9]; G. oregonensis McCauley et al. [23]; G. lobata Byrd [24]; G. trematomus Byrd [24]; G. japonica Toman [25]; and G. caetorinchi Machida and Kuramochi [26]. Morphological and morphometric comparison revealed that in our study, the Gonocerca species is closely related to G. phycidis previously described by Zdzitowiecki [27] from Pseudochaenichthys georgianus in South Georgia; Suriano and Sutton [28] from Macroronus magellanicus in San Matías Gulf, Argentina; Kellermanns et al. [29] from Macrourus berglax in Admiralty Bay, Indian Ocean; and Guagliardo et al. [21] from Seriolella porosa in San Matías Gulf, Argentina; because of their remarkable similarities in the measurements of the different body parts. G. phycidis has a wide host range, infecting members of different fish families. However, it differs from G. oregonensis, which has paired fleshy oral lobes, larger sucker size, and four lobed vitellaria; from G. lobata Byrd, 1963 which has two masses of lobulated vitellaria; from G. japonica Toman [25] from Caelorinchus sp. in Suruga Bay, Japan, which has larger body size, higher sucker ratio, irregular testes and vitellaria shapes, and larger egg size; and from G. caelorinchi Machida and Kuramochi [26] from Caelorinchus japonicas in Suruga Bay, Japan which has smaller body size, remarkably larger pharynx size, ovary with irregular incisions, vitellaria composed of 3-8 lobes, and larger egg size.

\section{CONCULSION}

In view of all the above, the species found in $S$. undosquamis could be assumed to coincide with $G$. phycidis with a new host record in the Egyptian water.

\section{ACKNOWLEDGMENT}

Authors extend their appreciation for providing all facilities to complete this work to Faculty of Science, Cairo University, Cairo, Egypt. 


\section{REFERENCES}

[1] Manter HW. 1925. Some marine fish trematodes of Maine. Journal of Parasitology 12: 11-18.

[2] Skrjabin KI, Guschanskaja LH. 1955. Suborder Hemiurata (Markevitsch, 1951) Skrjabin et Guschanskaja, 1954. Part 3. Osnovy Trematodologii 11: 465-748.

[3] Nicoll W. 1910. On the entozoa of fishes from the Firth of Clyde. Parasitology 3: 322-359.

[4] Gibson DI. 1976.Monogenea and Digenea from fishes. Discov Rep 36: 179-266.

[5] Gibson DI and Bray RA. 1979. The Hemiuroidea: Terminology, systematics and evolution. Bulletin of the British Museum (Natural History) Zoology Series 36: 35-146.

[6] Gibson DI. 1996.Trematoda, L. Margolis, Z. Kabata (Eds.), Guide to the Parasites of Fishes of Canada, Part IV, NRC Research Press, Ottawa, pp. 1-373.

[7] Gibson DI. 2002. Family derogenidae Nicoll, 1910, in: D.I. Gibson, A. Jones, R.A. Bray (Eds.), Keys to the Trematoda, vol. I, CAB International, Wallingford, pp. 351-368.

[8] Manter HW. 1934. Some digenetic trematodes from deep-water fish of Tortugas, Florida. Papers from the Tortugas Laboratory 28: 261-345.

[9] Wolfgang RW, Myers BJ. 1954. Gonocerce macroformis sp. nov. (Derogenetinae, Hemiuridae) from the ovary of the cod. Canadian Journal of Zoology 32: 25-29.

[10] Gaevskaya AV. 1975. Two new species of trematodes Gonocera macrouri n. sp. and Hemiurus macrouri n. sp. from Macrourus rupestris in the North Eastern Atlantic. Parasitology 9: 475-479.

[11] Ronald K. 1960. The metazoan parasites of the Heteroso ate of the Gulf of St.Lawrence. VI. Digenea. Canadian Journal of Zoology 38:923-937.

[12] Szuks H. 1975. Zum Befall von Macrourus rupestris (Gunnerus) aus dem Bereich von Labrador mit digenen Trematoden. Wiss. Z. Pad. Hochsch."Lise/otte Hermann."Gustrow, Math.-Naturwiss.Fak., 2: 225-231.

[13] Zubchenko AV (1981) Parasitic fauna of some macrouridae in the Northwest Atlantic. Journal of Northwest Atlantic Fishery Science 3: 67-72.

[14] Brinkmann A. 1975. Trematodes from Greenland. Meddelelser om Grønland. 205(2): 1-88.

[15] Campbell RA, Munroe TA. 1977. New hemiurid trematodes from deep-sea benthic fishes in the Western North Atlantic. Journal of Parasitology 63(2): 285-294.

[16] Bush AO, Lafferty KD, Lotz JM, Shostak AW. 1997. Parasitology meets ecology on its own terms: Margolis et al. revisited. Journal of Parasitology 83: 575-583.

[17] Guidelli GM, Tavechio WL, Takemoto RM, Pavanelli GC. 2006. Fauna parasitária de Leporinus lacustris e Leporinus friderici (Characiformes, Anostomidae) da Planície de Inundaçãodo Alto Rio Paraná, Brasil. Acta Scientiarum 28 (3): 281-290.

[18] Lerssutthichawal T. 1999. Monogeneans of the Freshwater Siluriform Fishes of Thailand.Ph.D. thesis.University of Malaya.

[19] Bassey SE. 2011.A Concise Dictionary of Parasitology. 1st Edn., Zetus Concepts, Port Harcourt, pp: 115.

[20] Abdel-Ghaffar F, Abdel-Gaber R, Bashtar AR, Morsy K, Al Quraishy S, Saleh R, Mehlhorn H. 2015. Molecular characterization and new geographical record of Lecithochirium priacanthi (Digenea, Hemiuridae) infecting the moontail bullseye fish Priacanthus hamrur (Perciformes, Priacanthidae) from the Red Sea, Egypt. Parasitology Research 114: 4471-4477.

[21] Guagliardo ES, Schwerdt CB, Martorelli SR, Galeano NA, Tanzola RD. 2010. Digenean trematodes of Seriolella porosa (Pisces, Centrolophidae) in San Matías Gulf, Argentina. Acta Parasitologica 55(1): 29-38.

[22] Layman EM. 1930. Parasitic worms from the fishes of Peter The Great Bay. Izvestiya Tikhookeanskoi Nauchno Promyslovoi Stantsii 3: 1-120.

[23] McCauley JE, Pequegnat JE, Brownell CL. 1970. A new species of Gonocerca Manter, 1925 (Trematoda, Hemiuridae) from the Eastern Pacific. Proceedings of the Helminthological Society of Washington 37: 169-171.

[24] Byrd MA. 1963. Helminth Parasites of Antarctic Vertebrates. Part I. Digenetic Trematodes of Marine Fishes. Proceedings of the Helminthological Society of Washington 30: 129-148.

[25] Toman G. 1973. A new digenetic trematode, Gonocerca japonica n. sp. (Hemiurida, Gonocercinae) from the stomach of a rat-tail fish, Coelorltynchus sp., from Japan. Japanese Journal of Parasitology 22: 59-62.

[26] Machida M, Kuramochi T. 1994. Two new species of trematodes (Gorgoderidae and Lepocreadiidae) from deep-sea fishes of Suruga Bay, Japan. Bulletin of the National Science Museum [Tokyo, Japan] 20: 149-153. 

undosquamis

[27] Zdzitowiecki K. 1979. Digenetic trematodes in alimentary tracts of fishes of South Georgia and South Shetland (Antarctica).Acta Ichthyologica et Pisecatoria 9: 15-31.

[28] Suriano DM, Sutton CA. 1981. Contribucion al conocimiento de la fauna parasitologica Argentina. VII. Digeneos de peces de la plataformadel mar Argentino. Revista del Museo de la Plata (Nueva Serie, Seccion Zoologica) 12: 261-271.

[29] Kellermanns E, Klimpel S, Palm HW. 2009. Parasite fauna of the Mediterranean grenadier Coryphaenoides mediterraneus (Giglioli, 1893) from the Mid-Atlantic Ridge (MAR). Acta Parasitologica 54: $158-164$.

Citation: Rewaida Abdel-Gaber., et.al," Morphological and Morphometric Insights of Gonocerca phycidis from the Brushtooth Lizardfish Saurida undosquamis" International Journal of Research Studies in Zoology, vol. 5, no. 4, p. 16-21, 2019. DOI: http://dx.doi.org/10.20431/2454-941X.050403.

Copyright: (C) 2019 Authors. This is an open-access article distributed under the terms of the Creative Commons Attribution License, which permits unrestricted use, distribution, and reproduction in any medium, provided the original author and source are credited. 